REVIEW ARTICLE

\title{
HONEY ACCELERATES WOUND HEALING IN PRESSURE ULCER:
} A REVIEW

\author{
Jessica Halim¹, \& Noto Dwimartutie ${ }^{2}$ \\ 1. Faculty of Medicine, Universitas Indonesia, Jakarta, Indonesia \\ 2. Division of Geriatric, Department of Internal Medicine, Faculty of Medicine Universitas Indonesias, Cipto Mangunkusumo \\ Hospital, Jakarta, Indonesia
}

Introduction: Pressure ulcer (PU) is a result of prolonged pressure and shear over a bony prominence resulting in tissue injury of varying depth. To date, there is no standardized wound dressings for PU. Due to its availability and affordability, honey is suitable as PU wound dressing considering its anti-oxidant, anti-inflammatory, and antibacterial properties. This review article will provide evidence of the superiority of honey dressing.

Methods: Literature source was searched through online databases with relevant keywords and then appraised for their validity, importance, and applicability. Total of three articles were appraised.

Results: All articles agreed that application of honey on PU wounds reduced wound size and alleviate pain. Honeyimpregnated gauze dressing promoted faster pain relief throughout treatment and less discomfort during each dressing change. Healing rate was proven 4 times faster with honey compared to other topical ointments. However, the antibacterial effect of honey was not significantly confirmed in the study. Nonetheless, topical application of honey successfully accelerates wound healing in PU.

Conclusion: Honey is a promising alternative for topical dressings in patients with PU.

Keywords. Honey, Honey dressings, Pressure Ulcer, Wound Healing, Pain Relief

Pendahuluan: Ulkus decubitus (UD) merupakan akibat dari tekanan dan gesekan yang berkepanjangan di area penonjolan tulang yang mengakibatkan cedera pada jaringan dengan kedalaman yang bervariasi. Sampai saat ini, belum ada dressing luka terstandarisasi untuk UD. Meninjau aspek ketersediaan dan keterjangkauan, madu cocok digunakan sebagai dressing luka UD karena mengandung anti-oksidan, anti-inflamasi, dan antibakteri. Artikel ini bertujuan untuk menyelidiki keunggulan dressing madu dibandingkan dressing modern lainnya.

Metode: Literatur dicari melalui database online dengan kata kunci yang relevan dan kemudian dinilai validity (V), importance (I), dan applicability (A). Total tiga artikel dibahas dalam artikel review ini.

Hasil: Semua artikel sepakat bahwa aplikasi madu pada luka UD mengurangi ukuran luka dan mengurangi rasa sakit. Kain kasa yang direndam madu dapat menghilangkan rasa sakit lebih cepat selama perawatan dan mengurangi rasa tidak nyaman setiap penggantian dressing. Penyembuhan luka terbukti 4 kali lebih cepat dengan madu dibandingkan dengan dressing topikal lainnya. Efek antibakteri madu tidak dapat dikonfirmasi secara signifikan dalam penelitian ini. Meskipun demikian, dressing madu berhasil mempercepat penyembuhan luka pada pasien dengan UD.

Kesimpulan: Madu merupakan alternatif dressing topikal yang menjanjikan pada pasien dengan UD.

Kata kunci. Madu, Dressing Madu, Ulkus Dekubitus, Penyembuhan Luka, Nyeri

Conflicts of Interest Statement:

The author(s) listed in this manuscript declare the absence of any conflict of interest on the subject matter or materials discussed. 


\section{INTRODUCTION}

Pressure ulcer is a localized wound as a result of prolonged pressure and shear over a bony prominence, which leads to tissue injury of varying depth. ${ }^{1}$ Constant pressure put over a long period of time may cause tissue ischemia, cessation of oxygen supply and nutrition, and eventually tissue necrosis, leading to distortion and deformation and damage. Pressure ulcer develops over time in patients with immobility and activity limitation, bedridden, or chair bound, accompanied with predisposing factors such as loss of movements, loss of sensation, and failure of reactive hyperaemia. ${ }^{2}$ Pressure ulcer is categorized into 6 classes by National Pressure Ulcer Advisory Panel (NPUAP): stage 1-4, unstageable, and deep tissue injury. ${ }^{3}$

Various methods for treating pressure ulcer have been religiously studied, such as pressure redistribution, nutritional support, and local wound care. Dressings should possess 3 essential properties: facilitate autolytic debridement, provide moisture, and control bacterial load. ${ }^{4}$ Majority of dressings, namely the polyurethane, foam, alginate, nano-crystalline silver dressing, can aid effective wound reduction, prevent secondary infection and suppress exudate production. ${ }^{5}$ However, no gold standard has been established for the type of dressing suitable for pressure wound. The choices are usually tailored for specific wound staging, which are limited to the site of the ulcer, availability, personal preference, and the cost.

Honey was first recognized as topical antimicrobial agent in 1892, and has been widely used as wound dressing due to its anti-oxidant, anti-bacterial, anti-inflammatory properties. ${ }^{6}$ Honey may also inhibit biofilm production, reduce malodor, provide autolytic debridement, and induce anti-inflammatory effect. Antibacterial property of honey comes from the hyperosmotic sugar content, production of hydrogen peroxide from honey enzyme, and its acidic $\mathrm{pH}$. Honey also possesses strong osmotic activity which pulls out fluid from the wound surface, creating a layer of fluid preventing honey to adhere to the wound bed.6,7 This will alleviate pain and destruction of granulation tissue during removal of the dressings.

Manuka honey was proven to have broad spectrum antimicrobial properties towards Staphylococcus aureus, Pseudomonas aeruginosa, and Methicillin -Resistant Staphylococcus Aureus (MRSA). ${ }^{4}$ One study compared the use of honey and silver sulfadiazine dressing in burn patients, only to show that honey dressings sterilize wound faster, enhance granulation, epithelization, reduce hypertrophic scar and burn contractures. ${ }^{8}$ Honey was proven superior compared to povidone iodine in reducing wound size and pain score and increasing comfort when applied onto chronic wounds. ${ }^{9}$ Albeit all these facts, the application of honey for PU is still understudied. This study aims to explore and analyze the efficacy of honey-impregnated dressings on wound healing in PU through compilation of pre-existing research studies.

\section{METHODS}

\section{Case Illustration}

A 64-year-old woman presented with persistent pressure sore to our institution. Reduced intake, lethargy, and significant body weight loss were reported. The patient got amputed on both of her feet thumbs due to gangrenous diabetic wound, which has caused postural instability. Patient is now bedridden with unhealed pressure ulcer wound on her buttocks. Patient suffered from Diabetes Mellitus (DM) Type 2 for 10 years ago and sufficiently treated.

General examination showed a stable vital sign with ideal body mass index. Physical evaluation revealed a bandaged left thumb postamputation and a red dimpled pressure ulcer on the right buttock. Size is about $7 \times 3 \mathrm{~cm} 2$ with sharp edges, subcutaneous layer on the surface, no blood, no pus, no granulation, no malodor, no signs of inflammation. Patient was diagnosed with Pressure Ulcer grade 3. We wondered whether there is a more accessible and costeffective dressing that can be easily applied to accelerate wound healing.

\section{Search Strategy}

Based on the case illustration and aforementioned supporting literatures, this clinical question was raised, "can honey accelerate wound healing in pressure ulcer?". Participants (P) selected for this study are patients with pressure ulcer of any staging and underlying medical condition. The intervention (I) will involve the application of honey. Since there is no standardized PU dressing, this report will be compared (C) honey with other topical 
dressing. Wound size reduction or pain relief will be recorded as the outcomes $(\mathrm{O})$.

Literature source was searched through 3 databases, namely Pubmed $\AA$, Cochrane $\AA$, and Scopus ${ }^{\circledR}$ on November 29th 2019 . The keywords are "honey", "pressure ulcer", and "wound healing". Each of them is adjusted to MeSH terms, searched for the synonyms and combined using Boolean tools. Search strategy is described in Table 1.

Table 1. Literature Search Strategy

\begin{tabular}{|c|c|c|c|}
\hline Database & Search Strategy & Hits & $\begin{array}{l}\text { Screened } \\
\text { Articles }\end{array}$ \\
\hline PubMed ${ }^{\circledR}$ & $\begin{array}{l}(((\text { honey or alginate honey or Manuka honey or } \\
\text { MediHoney)) AND (pressure ulcer or ulcus decubitus or } \\
\text { decubitus ulcer or pressure sore or bed sore)) AND (wound } \\
\text { healing or wound reduction or pain) })^{+}\end{array}$ & 20 & 5 \\
\hline $\begin{array}{l}\text { Cochrane }{ }^{\circledR} \text { (Reviews and } \\
\text { Trials) }\end{array}$ & $\begin{array}{l}(((\text { honey or alginate honey or Manuka honey or } \\
\text { MediHoney)) AND (pressure ulcer or ulcus decubitus or } \\
\text { decubitus ulcer or pressure sore or bed sore)) AND (wound } \\
\text { healing or wound reduction or pain) }\end{array}$ & 13 & 1 \\
\hline Scopus & $\begin{array}{l}\text { (TITLE-ABS-KEY (honey AND dressings OR honey OR } \\
\text { honey AND wound AND dressings) AND TITLE-ABS- } \\
\text { KEY (pressure AND ulcer OR decubitus AND ulcer) AND } \\
\text { TITLE-ABS-KEY (wound AND healing OR pain)) }\end{array}$ & 26 & 2 \\
\hline Manual Search & Honey AND Pressure Ulcer AND Wound Healing & - & 2 \\
\hline
\end{tabular}

Articles were retrieved from different databases. Selection was cautiously performed based on title and abstract screening, categories of research studies, and full text screening. Inclusion criteria include studies that compare honey and other topical agents for PU with broad range of outcomes: wound size reduction, pain score decrement, or bacteriological profile. Articles excluded are non-English literatures.

\section{RESULTS}

After a meticulous search from all electronic databases, 10 articles were retrieved after title and abstract screening. There are 4 duplicates out of 10, leaving only 6 articles selected for full text screening. After a thorough read, three articles were excluded: one nonEnglish literature, one case report of only 2 patients, and one observational clinical trial without comparison with other conventional treatment. In the end, three articles were selected for appraisal. They are studies by Khadanga et al. $(2015)^{10}$, Saha et al. (2012) ${ }^{11}$, and Günes et al. $(2007)^{12}$. Literature search is summarized in Figure 1.

Three articles are appraised for validity (V), importance (I), and applicability (A).
Appraisal is processed with standard therapeutic validity criteria provided by Oxford Center of Evidence-Based Medicine (CEBM) 201113. Results is presented in Table 2, 3 and 4.

Papers by Khadanga et al., Saha et al., and Günes et al. are appraised using CEBM appraisal list. The study designs are case control (IIIB), cohort (IIB), and Randomized Clinical Trial (RCT) (IB), respectively. The number of participants involved in the study are not enough to replicate native population. But results are significant and deemed important.

All papers were randomized, shared similarity of baseline demography, and participants were equally treated throughout the entire study. They were measured and analyzed in the group in which they were randomized. Only one study by Khadanga $^{10}$ applied a single-blind randomization. Günes and colleagues ${ }^{12}$ did not perform blinding to the examiners because to actually do blinding, they needed to clean the wound after dressing removal. This would annul the initially-intended examinations because they needed to identify the slough and the exudates on the wound bed. 


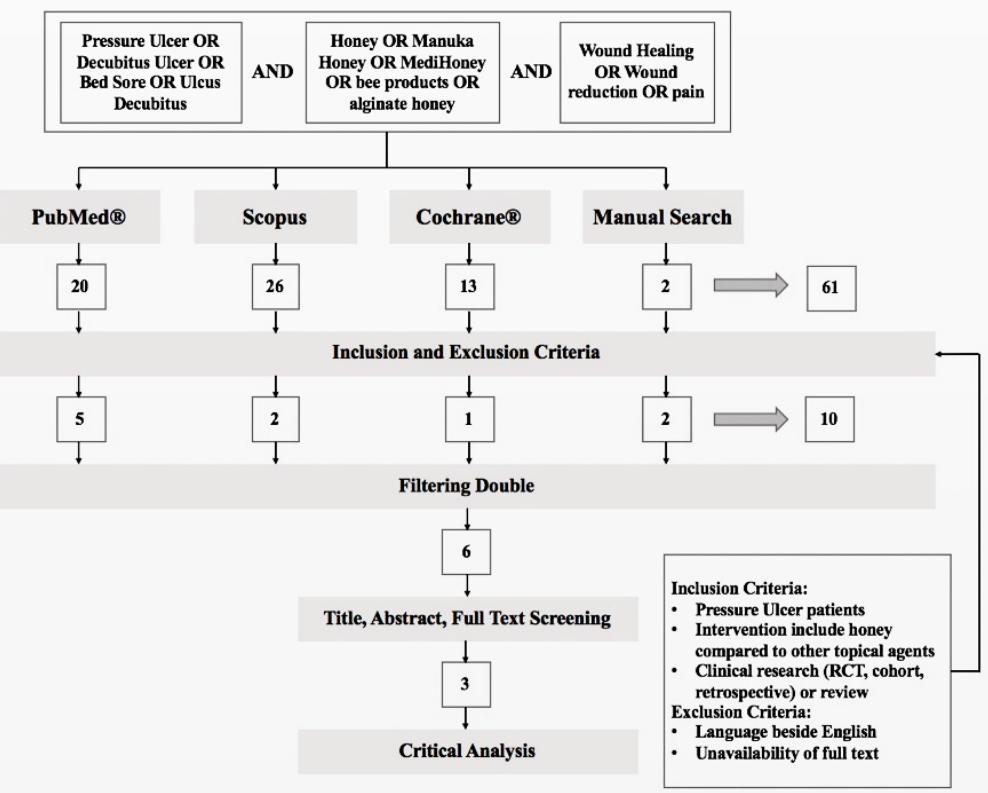

Figure 1. Literature search strategy (on November 29th 2019)

Table 2. Critical Appraisal - Validity.

\begin{tabular}{|c|c|c|c|c|c|c|c|c|}
\hline \multirow[b]{2}{*}{ Article } & \multirow[b]{2}{*}{ Year } & \multicolumn{7}{|c|}{ Validity } \\
\hline & & $\begin{array}{l}\text { Study } \\
\text { Design }\end{array}$ & NoP & Randomization & $\begin{array}{l}\text { Similarity } \\
\text { of } \mathrm{T} \text { and } \mathrm{C} \\
\text { Group }\end{array}$ & Blinding & $\begin{array}{l}\text { Equal } \\
\text { Treatment }\end{array}$ & ITT \\
\hline $\begin{array}{l}\text { Khadanga } \\
\text { et al. }\end{array}$ & 2015 & $\begin{array}{l}\text { Case } \\
\text { Control }\end{array}$ & 40 & Yes & Yes & $\begin{array}{l}\text { Single- } \\
\text { blind }\end{array}$ & Yes & NR \\
\hline Saha et al. & 2012 & Cohort & 40 & Yes & Yes & No & Yes & NR \\
\hline $\begin{array}{l}\text { Günes et } \\
\text { al. }\end{array}$ & 2007 & RCT & 26 & Yes & Yes & No & Yes & NR \\
\hline
\end{tabular}

Table 3. Critical Appraisal - Importance, Applicability

\begin{tabular}{|c|c|c|c|c|c|c|c|c|c|}
\hline \multirow[b]{2}{*}{ Article } & \multirow[b]{2}{*}{ Year } & \multicolumn{4}{|c|}{ Importance } & \multicolumn{3}{|l|}{ Applicability } & \multirow[b]{2}{*}{$\begin{array}{l}\text { Level of } \\
\text { Evidence }\end{array}$} \\
\hline & & CER & EER & ARR & NNT & $\begin{array}{l}\text { Availability } \\
\text { of } \\
\text { Treatment }\end{array}$ & $\begin{array}{l}\text { Similarity } \\
\text { of Patients }\end{array}$ & $\begin{array}{l}\text { Clinically } \\
\text { Important } \\
\text { Outcome }\end{array}$ & \\
\hline $\begin{array}{l}\text { Khadan } \\
\text { ga et al. }\end{array}$ & 2015 & NR & NR & NR & NR & Yes & Yes & Yes & IIIB \\
\hline $\begin{array}{l}\text { Saha et } \\
\text { al. }\end{array}$ & 2012 & NR & NR & NR & NR & Yes & Yes & Yes & IIB \\
\hline $\begin{array}{l}\text { Günes et } \\
\text { al. }\end{array}$ & 2007 & NR & NR & NR & NR & Yes & Yes & Yes & IB \\
\hline
\end{tabular}


The importance of the study is described by Günes and colleagues in which they showed a 4 time-increased rate in wound healing after treated with honey. Results were reported in Pressure Ulcer Scale of Healing (PUSH) tool as standardized measurement of PU.

All results are displayed in numerical data and thus cannot be translated into a dichotomous two-times-two table to be analyzed for control event rate (CER), experimental event rate (EER), absolute risk reduction (ARR), and number needed to treat (NNT). Khadanga paper analyzed bacteriological profiling, pain score, and wound size reduction presented in numerical difference before and after application. Saha 11 and colleagues described pain relief score and wound assessment using the Bates-Jensen scale. Mean scores, standard deviation, and standard error were provided to describe chance variation.

Having appraised the validity and benefit of the study, it is necessary to analyze applicability to local patient care. Considering the inclusion and exclusion criteria and the similar baseline characteristics of the patients, the results are likely applicable to patients in Indonesia. However, there may be some differences in composition of the honey and underlying diseases which vary in each patient.

Both Khadanga and Saha did not mention which honey was used for the study and how they layered the wounds. All in all, the use of honey for dressing PU possess undoubtable benefit compared to modern dressing. Every single literature comparing honey and other treatments highlighted the benefit of honey as wound dressing. It is easily available and affordable, thus suitable for patients with limited resources. Moreover, its natural properties pose no significant adverse effect for long-term use.

Table 4. Summary of Appraisal of The Selected Articles

\begin{tabular}{|c|c|c|c|c|c|c|c|c|}
\hline \multirow[t]{2}{*}{ Articles } & \multirow[t]{2}{*}{ Year } & \multicolumn{3}{|c|}{ Participants } & \multirow{2}{*}{$\begin{array}{l}\text { Wound } \\
\text { size }\end{array}$} & \multirow[t]{2}{*}{ Treatment } & \multirow[t]{2}{*}{ Control } & \multirow[t]{2}{*}{ Dur. } \\
\hline & & NoP & $\begin{array}{l}\text { PU } \\
\text { Grading }\end{array}$ & Comorbid & & & & \\
\hline $\begin{array}{l}\text { Khadang } \\
\text { a et al. }\end{array}$ & 2015 & 40 & NR & NR & $\begin{array}{l}\text { Size } \\
\text { greater } \\
\text { than } \\
12 \mathrm{~cm} 2\end{array}$ & $\begin{array}{l}\text { Honey } \\
\text { (Group A) }\end{array}$ & $\begin{array}{l}\text { Povidone } \\
\text { Iodine } \\
\text { (Group B) }\end{array}$ & $\begin{array}{l}10 \text { days } \\
\text { (Day } 1 \\
\text { and Day } \\
\text { 10) }\end{array}$ \\
\hline Saha et al. & 2012 & 40 & NR & $\begin{array}{l}\text { End Stage } \\
\text { Cancer }\end{array}$ & NR & $\begin{array}{l}\text { Honey with } \\
\text { metronidazo } \\
\text { le powder }\end{array}$ & $\begin{array}{l}\text { Metronid } \\
\text { azole } \\
\text { Powder }\end{array}$ & 10 days \\
\hline $\begin{array}{l}\text { Günes et } \\
\text { al. }\end{array}$ & 2007 & 26 & $\begin{array}{l}\text { PU Stage } \\
\text { II or III }\end{array}$ & $\begin{array}{l}\text { NR (Diabetes } \\
\text { and critical } \\
\text { illness were } \\
\text { excluded) }\end{array}$ & NR & $\begin{array}{l}\text { Unproccesse } \\
\text { d Honey }\end{array}$ & $\begin{array}{l}\text { Ethoxy- } \\
\text { diaminoa } \\
\text { cridine } \\
\text { plus } \\
\text { nitrofuraz } \\
\text { one } \\
\text { dressing } \\
\end{array}$ & 5 weeks \\
\hline
\end{tabular}

Legend: Dur. $=$ duration; NoP=Number of Patients; NR= Not Reported; PU= Pressure Ulcer 
Table 4 (Continued). Summary of Appraisal of The Selected Articles

\begin{tabular}{|c|c|c|c|c|}
\hline \multirow[t]{2}{*}{ Articles } & \multicolumn{3}{|c|}{ Results } & \multirow[t]{2}{*}{ Conclusion } \\
\hline & Wound Healing & Bacteriological Profile & Pain Score & \\
\hline $\begin{array}{l}\text { Khadanga et } \\
\text { al. }\end{array}$ & $\begin{array}{l}\text { Wound size reduction is not } \\
\text { significant between Gr A and } \\
\mathrm{B}(\mathrm{p}=.459) \text {; reduced from } \\
\text { approx. } 33 \mathrm{~cm} 2 \text { to } 2.6 \mathrm{~cm} 2 \text { in } \mathrm{Gr} \\
\text { A; large outlier in the study } \\
\text { detected }\end{array}$ & $\begin{array}{l}\text { Day } 18 / 20 \text { bacteria }(+) \\
\text { in Gr A and } 9 / 20 \\
\text { bacteria }(+) \text { in Gr B } \\
\text { showed not much } \\
\text { difference. } \\
\text { Day } 102 / 20 \text { and } 1 / 20 \\
\text { bacteria }(+) \text { in Gr A and } \\
\text { B respectively }\end{array}$ & $\begin{array}{l}\text { Group A } \\
\text { experienced } \\
\text { less pain } \\
(p=.010)\end{array}$ & $\begin{array}{l}\text { Honey dressing } \\
\text { significantly } \\
\text { reduces pain. It is } \\
\text { safe, rost- } \\
\text { effective, readily } \\
\text { available, and } \\
\text { reduce wound } \\
\text { size. }\end{array}$ \\
\hline Saha et al. & $\begin{array}{l}\text { Honey group provides rapid } \\
\text { wound healing on day } 10 \\
\text { compared to control (F } \\
\text { value }>\text { critical difference; } \\
P>0.05)\end{array}$ & NR & $\begin{array}{l}\text { Pain control is } \\
\text { faster in } \\
\text { honey Group } \\
(\mathrm{F} \\
\text { value }>\text { critical } \\
\text { difference; } \\
\mathrm{P}>0.05)\end{array}$ & $\begin{array}{l}\text { Honey } \\
\text { application } \\
\text { promotes better } \\
\text { wound healing } \\
\text { and rapid pain } \\
\text { relief for PU in } \\
\text { cancer patients. }\end{array}$ \\
\hline Günes et al. & $\begin{array}{l}\text { Better PUSH tool score in } \\
\text { honey group }(\mathrm{p}<.001) ; 56 \% \\
\text { reduction in ulcer size in } \\
\text { honey group compared to } \\
13 \% \text { of comparison group } \\
(\mathrm{p}<.001) \text {; } 20 \% \text { patient } \\
\text { achieved complete healing in } \\
\text { treatment group compared to }\end{array}$ & NR & NR & $\begin{array}{l}\text { Healing in } \\
\text { subjects with } \\
\text { honey } \\
\text { application is } 4 \\
\text { times faster than } \\
\text { comparison } \\
\text { group }\end{array}$ \\
\hline
\end{tabular}

Legend: $G r=$ Group; $N R=$ Not Reported; $P U=$ Pressure Ulcer; $P U S H=$ Pressure Ulcer Scale of Healing

\section{DISCUSSION}

This is an evidence-based case report confirming the efficacy of honey dressings to accelerate healing in pressure ulcer compared to other established topical agents. All three articles agreed upon the superiority of honey as a promising alternative for PU dressings. However, the case control study by Khadanga et al. ${ }^{10}$ couldn't prove it significant due to lacking in number of participants. Nonetheless, all findings are in agreement with the results of former publications stating that topical application of honey is capable to accelerate wound healing in chronic wounds.

Khadanga publication had the most ideal outcomes, which include the bacteriological profiling of the wound bed, pain score decrement, and wound size reduction. The only downfall is that the author did not specify the PU grading, patients' comorbidities, and the type of honey used for the research. Saha and colleagues researched about honey with metronidazole versus metronidazole alone. Pain score relief and wound score reduction by Bates-Jensen assessment scale were observed. ${ }^{11}$ However, honey combined with antibiotic metronidazole could mask the anti-bacterial properties of honey. As a RCT study, Günes et al is an ideal reference for this report. They used standardized PUSH tool and compared the subjects periodically to record the wound healing rate. The only drawback is participants were limited to PU grade II or III.

The use of honey has evolved and become a natural therapeutic alternative for various 
medicinal purposes. ${ }^{7}$ This ancient remedy is superior in promoting wound healing by promoting granulation and epithelization when compared to polyurethane film, silver sulfadiazine, and amniotic membrane. ${ }^{6}$ It also possesses hygroscopic feature that draws moisture out and dehydrate bacteria while its high sugar content block bacterial penetration into the wound. Furthermore, its low $\mathrm{pH}$ prevent the microbial growth. ${ }^{14}$ The use of honey as wound dressing should not be limited to pressure ulcer.

Numerous studies have approved its efficacy in facilitating faster wound healing in post-operative wounds, infected wounds, acute wounds, or chronic wounds.15, 16 A study by Biglari et al tested MediHoney on PU of different grades, depths, sizes, and degrees of bacterial colonization in patients with spinal cord injury. At the end of the treatment, MediHoney was capable to decolonize all kinds of microbial load (including MRSA) within the first week and enhance tissue healing without inducing any allergic reaction and blood sugar level derailment in diabetic patients. ${ }^{17}$ Dunford reproduced similar result in a 12-week observation of patients with leg ulcers, concluding that Medihoney was a better choice in terms of odor control, ulcer size, pain relief, and patient satisfaction. ${ }^{18}$ Honey also possessed greater efficacy compared with silver sulfadiazine for superficial or partial thickness burn injuries as observed by Wijesinghe and colleagues. ${ }^{19}$

As illustrated, the patient suffered from PU grade 3 for 2 months without significant improvement. In this case, honey may be a suitable candidate for trial due to its well-known rapid healing properties. One observational study enrolled 20 patients with spinal cord injury who had PU grade III or IV and treated them with Manuka Honey. Results showed that 100\% wound site were void of bacteria on week 1 and $90 \%$ achieved complete healing on week 4 following application of honey-impregnated dressing. ${ }^{17}$ However, one retrospective study by Gilligan et al. showed that clostridial collagenase ointment (CCO) achieved faster granulation and tissue reepithelization compared to medicinal honey. ${ }^{20}$

There are two types of honey commonly used in research: natural honey and non-peroxide honey, known as medicinal Manuka Honey. ${ }^{14}$ Table honey possessed lower antibacterial activity and contained various microbial species compared to the sterile medical-grade honey. The medical grade honey was proven potent in-vitro against antibiotic-resistance bacteria due to the presence of catalase, methyl syringate and methylglyoxal. ${ }^{14}$, 21 More importantly, honey targets different parts of bacteria, unlike antibiotics, which makes bacteria more unlikely to develop resistance against honey. ${ }^{22}$ Antibacterial property of Manuka honey is associated with its Unique Manuka Factor (UMF), possessing diverse medicinal potency of interest. ${ }^{22}$ Combination of medical-grade honey and antibiotics may reduce the needed dose for antibiotic, minimize the risk of resistance, and increase the potency against antibiotic-resistance bacteria (eg. MRSA), ${ }^{23}$ which will be suitable for our patients with infectious wound site; postoperation, diabetic, pressure, or open tear wounds.

This is undeniably a promising field to explore. More RCT in larger scale should be conducted to achieve statistically significant outcomes. Further studies should observe the benefit of honey for advanced PU in comparison with other common dressings such as hydrocolloid, foam, hydrogel, or crystallinesilver dressings. Other outcomes should include scar reduction in burns or large surgical incisions. It is crucial to standardize the type of honey for less variable and more comparable results. Choices range from medicinal Manuka (Leptospermum) Honey to medical-grade Revamil or MediHoney. Being cost-friendly and readily available, honey should be widely utilized as wound dressing for preventing and treating PU.

\section{CONCLUSION}

Honey has the potential to accelerate healing in chronic PU and is proven safe and efficacious in all sorts of chronic wounds, including PU as shown in this study. Considering all the superior features the honey possesses, implementation is highly applicable in our hospital setting that is limited to cost and availability. The easily accessible source with no long-term adverse effects will make honey a perfect choice of dressing for this patient during her outpatient visits. Convenient application of honey gives an advantage for the caregivers. 
Correspondence regarding this article should be addressed to:

Jessica Halim. Faculty of Medicine, Universitas Indonesia, Jakarta, 10430, Indoneisa.

E-Mail: jessiica.halim@yahoo.com

\section{REFERENCES}

1. Harrison T, Kasper D. Harrison's principles of internal medicine. New York: McGrawHill Medical Publ. Division; 2015.

2. Bhattacharya S, Mishra RK. Pressure ulcers: Current understanding and newer modalities of treatment. Indian J Plast Surg. 2015;48(1):4-16.

3. Edsberg LE, Black JM, Goldberg $M$, et al. Revised National Pressure Ulcer Advisory Panel Pressure Injury Staging System: Revised Pressure Injury Staging System. J Wound Ostomy Continence Nurs. 2016;43(6):585-97.

4. Sood A, Granick MS, Tomaselli NL. Wound Dressings and Comparative Effectiveness Data. Adv Wound Care (New Rochelle). 3. United States2014. p. 511-29.

5. Volakakis E, Papadakis M, Manios A, et al. Platelet-rich Plasma Improves Healing of Pressure Ulcers as Objectively Assessed by Digital Planimetry. Wounds. 2019;31(10):252-6.

6. Yaghoobi R, Kazerouni A, kazerouni O. Evidence for Clinical Use of Honey in Wound Healing as an Anti-bacterial, Antiinflammatory Anti-oxidant and Anti-viral Agent: A Review. Jundishapur J Nat Pharm Prod. 2013;8(3):100-4.

7. Samarghandian S, Farkhondeh T, Samini F. Honey and Health: A Review of Recent Clinical Research. Pharmacognosy Res. 2017;9(2):121-7.

8. Gupta SS, Singh O, Bhagel PS, et al. Honey dressing versus silver sulfadiazene dressing for wound healing in burn patients: a retrospective study. J Cutan Aesthet Surg. 2011;4(3):183-7.

9. Gulati S, Qureshi A, Srivastava A, et al. A Prospective Randomized Study to Compare the Effectiveness of Honey Dressing vs. Povidone Iodine Dressing in Chronic Wound Healing. Indian J Surg. 2014;76(3):193-8.

10. Khadanga S, Dugar D, Karuna T, et al. Effects of Topical Honey Dressing in
Decubitus Ulcer. Asian Journal of Medical Sciences. 2015;6(4):99-101.

11. Saha A, Chattopadhyay S, Azam M, et al. The role of honey in healing of bedsores in cancer patients. South Asian J Cancer. 12012. p. 66-71.

12. Yapucu Gunes U, Eser I. Effectiveness of a honey dressing for healing pressure ulcers. J Wound Ostomy Continence Nurs. 2007;34(2):184-90.

13. CEBM. Therapy Study - Critical Apprasial University of Oxford: Center of EvidenceBased Medicine; 2011 [December 1st 2019]. Available from: https://www.cebm.net/wpcontent/uploads/2018/11/RCT.pdf.

14. Mandal MD, Mandal S. Honey: its medicinal property and antibacterial activity. Asian Pac J Trop Biomed. 2011;1(2):154-60.

15. Vyhlídalová D, Kozáková R, Zeleníková R. Management of non-healing wounds with honey dressings: A literature review Central European Journal of Nursing and Midwifery 2018;9(3):880-8.

16. Jull AB, Cullum N, Dumville JC, et al. Honey as a topical treatment for wounds. Cochrane Database Syst Rev. 2015(3):Cd005083.

17. Biglari $B$, vd Linden $\mathrm{PH}$, Simon $\mathrm{A}$, et al. Use of Medihoney as a non-surgical therapy for chronic pressure ulcers in patients with spinal cord injury. Spinal Cord. 2012;50(2):165-9.

18. Dunford CE, Hanano R. Acceptability to patients of a honey dressing for non-healing venous leg ulcers. J Wound Care. 2004;13(5):193-7.

19. Wijesinghe $M$, Weatherall M, Perrin K, et al. Honey in the treatment of burns: a systematic review and meta-analysis of its efficacy. N Z Med J. 2009;122(1295):47-60.

20. Gilligan AM, Waycaster CR, Bizier R, et al. Comparative Effectiveness of Clostridial Collagenase Ointment to Medicinal Honey for Treatment of Pressure Ulcers. Adv Wound Care (New Rochelle). 2017;6(4):12534.

21. Albaridi NA. Antibacterial Potency of Honey. International Journal of Microbiology. 2019;2019:1-10.

22. Johnston M, McBride M, Dahiya D, et al. Antibacterial activity of Manuka honey and its components: An overview. AIMS Microbiol. 42018. p. 655-64.

23. Jenkins R, Cooper R. Improving Antibiotic Activity against Wound Pathogens with 
Manuka Honey In Vitro. PLoS One. 2012;7(9):e45600.

\section{LIST OF ABBREVIATIONS}

EBCR - Evidence Based Case Report

MRSA - Methicillin-Resistant Staphylococcus

Aureus

NPUAP - National Pressure Ulcer Advisory

Panel

PRP - Platelet Rich Plasma

PU - Pressure Ulcer

PUSH - Pressure Ulcer Scale of Healing

UMF - Unique Manuka Factor

VAS - Visual Analogue Scale 